\section{(1)}

CrossMark

\title{
The epidemiology of idiopathic pulmonary fibrosis and interstitial lung diseases at risk of a progressive-fibrosing phenotype
}

\author{
Amy L. Olson ${ }^{1}$, Alex H. Gifford ${ }^{2}$, Naohiko Inase ${ }^{3}$, Evans R. Fernández Pérez ${ }^{1}$ and \\ Takafumi Suda ${ }^{4}$
}

Affiliations: ${ }^{1}$ Interstitial Lung Disease Program, Autoimmune Lung Center, Division of Pulmonary and Critical Care Medicine, National Jewish Health, Denver, CO, USA. ${ }^{2}$ Dartmouth-Hitchcock Medical Center, Section of Pulmonary and Critical Care Medicine, One Medical Centre Drive, Lebanon, NH, USA. ${ }^{3}$ Dept of Respiratory Medicine, Tokyo Medical and Dental University, Tokyo, Japan. ${ }^{4}$ Second Division, Dept of Internal Medicine, Hamamatsu University School of Medicine, Hamamatsu, Shizuoka, Japan.

Correspondence: Amy L. Olson, Interstitial Lung Disease Program, Autoimmune Lung Center, Division of Pulmonary and Critical Care Medicine, National Jewish Health, 1400 Jackson Street, Denver, C0 80206, USA. E-mail: olsonađnjhealth.org

@ERSpublications

ILDs with a progressive-fibrosing phenotype appear to be more common in older adults and are associated with a complex network of environmental and genetic factors. Further epidemiological studies are warranted to help identify these patients. http://ow.ly/SY6m30mWytM

Cite this article as: Olson $\mathrm{AL}$, Gifford $\mathrm{AH}$, Inase $\mathrm{N}$, et al. The epidemiology of idiopathic pulmonary fibrosis and interstitial lung diseases at risk of a progressive-fibrosing phenotype. Eur Respir Rev 2018; 27: 180077 [https://doi.org/10.1183/16000617.0077-2018].

ABSTRACT The availability of epidemiological data relating to interstitial lung diseases (ILDs) has increased over recent years, but information on the prevalence and incidence of ILDs of different aetiologies remains limited. Despite global distribution, the proportion of patients who develop a progressive phenotype across different ILDs is not well known. Disease behaviour is well documented in idiopathic pulmonary fibrosis but idiosyncratic in other ILDs that may present a progressive fibrosing phenotype. Possible reasons may include the heterogeneous nature of the aetiology, the complexity of diagnosis (and subsequent documentation of cases) and the methods employed to retrospectively analyse patient databases. This review presents a broad overview of the epidemiological data available for ILDs that may present a progressive-fibrosing phenotype, collectively and stratified according to clinical classification. We also note where further data are needed in comparison to the well-studied IPF indication.

\section{Introduction}

Interstitial lung diseases (ILDs) are rare diseases that share a number of common clinical and pathophysiological features, but also demonstrate a diverse aetiology and prognosis [1]. Varying proportions of patients with ILDs develop a chronic progressive-fibrosing phenotype. Idiopathic pulmonary fibrosis (IPF) can be viewed as the prototype progressive-fibrosing ILD; it is relatively well understood both in terms of epidemiology and disease behaviour $[2,3]$. While IPF is by definition a chronic progressive-fibrosing interstitial pneumonia [4], only a proportion of patients with other ILDs develop this phenotype. In those other ILDs, progressive fibrosis can develop at any time during the disease course, but very little is known about why and how frequently this occurs [2]. A terminology recently used to describe fibrosing ILDs with a progressive phenotype is progressive-fibrosing ILD (PF-ILD) [2]. For details on the

Provenance: Publication of this peer-reviewed article was sponsored by Boehringer Ingelheim Pharmaceuticals Inc., Ridgefield, CT, USA (principal sponsor, European Respiratory Review issue 150).

Received: Aug 152018 | Accepted after revision: Nov 212018

Copyright CERS 2018. ERR articles are open access and distributed under the terms of the Creative Commons Attribution Non-Commercial Licence 4.0. 
diagnosis and clinical course of ILDs with a progressive-fibrosing phenotype, please refer to CotTIN et al. [5] in this issue of the European Respiratory Review. Data on the prevalence and incidence of ILDs other than IPF with a progressive-fibrosing phenotype are limited, in part due to the complexity and rarity of diagnosis. Consequently, meaningful comparisons of the epidemiology of different PF-ILDs are difficult. This review presents a broad overview of the epidemiological data that are available in relation to ILDs that may present a progressive-fibrosing phenotype, collectively and stratified according to clinical classification, while noting the gaps where further data are needed. Epidemiological data relating specifically to the proportion of patients who develop progressive fibrosis within each of the differing ILDs is not very well documented; therefore, unless specified, the data considered here relate more generally to ILDs, of which a proportion of patients may present with a progressive-fibrosing phenotype.

\section{The epidemiology of IPF \\ Incidence, prevalence and patient demographics}

IPF can be used as a model when considering other ILDs with a progressive-fibrosing phenotype [2]. It primarily occurs in older adults and is characterised by progressive worsening of dyspnoea and lung function [4, 6]. Risk factors reported to be associated with IPF include cigarette smoking, environmental exposures, microbial pathogens and genetic risk factors [4].

Epidemiological data for IPF can vary widely due to variations in the data collection methods and classification terms used (table 1) [11, 12]. Throughout Europe and North America, the estimated incidence of IPF has been reported to range between 2.8 and 19 cases per 100000 people per year [23-25]. An analysis of national admissions data in Canada reported a higher rate of IPF than other national estimates, with an incidence rate of 18.7 per 100000 cases and a broad prevalence of 41.8 per 100000 cases, but noted that direct comparisons were not possible [26]. To further illustrate this point, a recent retrospective analysis of data from at-risk adults in Northern California carried out between 2000 and 2014, applied a commonly used case-finding algorithm to estimate an incidence rate of 6.8 per 100000 person-years, whereas incidence was lower when using a modified algorithm with an enhanced predictive value (5.6 per 100000 person-years) [11]. In a second analysis of data from a nationwide database in the USA, the age-standardised, positive value-corrected incidence of IPF was higher, estimated to be 14.6 per 100000 person-years with a period prevalence of 58.7 per 100000 persons [12].

The highest rates of IPF in Europe are reported in the UK, with incidence rates between 4.6 and 8.65 per 100000 people per year, and 6000 people diagnosed annually $[6,23]$. The incidence of IPF appears to be lower in Scandinavia, with incidence reported between 1.3 and 4.3 per 100000 people per year [23]. In Russia, the incidence rate has been estimated to be 4-6 per 100000 people per year [27]. The lowest rate of IPF globally is in Asia (South Korea, Taiwan and Japan), with incidence rates ranging from 1.2 to 4.16 per 100000 people per year [23].

The prevalence of IPF increases with age, with the majority of patients aged $>50$ years at diagnosis and a higher proportion of males than females $[6,25,26,28,29]$. A regional observational study of ILD diagnoses performed by Duchemann et al. between January and December 2012 in Seine-Saint-Denis, a multi-ethnic county of Greater Paris in France, reported a prevalence rate for IPF of 8.2 per 100000 [24]. In Canada, the prevalence of IPF was reported to increase from 25.9 per 100000 population in patients aged 50-59 years, to 507.0 per 100000 population at $\geqslant 90$ years of age [26]. In the UK, 85\% of patients diagnosed with IPF are $>70$ years [6]. However, it is worth noting that a small subset of patients with IPF $(0.5-3.7 \%)$ may present with familial IPF, in whom the onset of the disease can be earlier [28, 30, 31].

\section{The epidemiology of fibrosing ILDs that may present a progressive phenotype, other than IPF \\ Idiopathic interstitial pneumonias}

Idiopathic interstitial pneumonia (IIP) is a term used to describe a wide range of ILDs characterised by unique clinical, radiological and pathological features [32-34]. Diagnosis of patients with IIP can be challenging due to the mixed patterns of lung injury that may be observed $[32,33]$.

\section{Idiopathic nonspecific interstitial pneumonia}

Idiopathic nonspecific interstitial pneumonia (iNSIP) is a form of IIP that was first introduced as a distinct entity in 2008 [32]. Only a limited number of iNSIP epidemiological studies have been performed.

\section{Incidence, prevalence and patient demographics}

The general incidence of iNSIP (regardless of progressive-fibrosing phenotype) is lower than in IPF, with retrospective data of mixed cohorts of IPF and iNSIP patients estimating the prevalence of iNSIP to be 1-9 per 100000 compared with 2-20 per 100000 for IPF [35]. The demographic profile of patients with iNSIP 
TABLE 1 Incidence of idiopathic pulmonary fibrosis (IPF) in studies using large databases

\begin{tabular}{|c|c|c|c|c|c|c|c|c|c|}
\hline First author [ref.] & Year & Location & $\begin{array}{l}\text { Years } \\
\text { studied }\end{array}$ & $\begin{array}{l}\text { Data source } \\
\text { type }\end{array}$ & $\begin{array}{l}\text { Condition } \\
\text { studied }\end{array}$ & $\begin{array}{c}\text { Case } \\
\text { definition }\end{array}$ & $\begin{array}{c}\text { Population } \\
\text { demographics }\end{array}$ & $\begin{array}{l}\text { Incidence per } \\
100000 \text { per } \\
\text { year }^{\#}\end{array}$ & $\begin{array}{l}\text { Rate } \\
\text { type }\end{array}$ \\
\hline \multicolumn{10}{|c|}{ Large database studies } \\
\hline \multicolumn{10}{|c|}{ Europe } \\
\hline MAHER [7]" & 2013 & UK & $2000-2012$ & $\begin{array}{c}\text { Nationwide } \\
\text { primary care } \\
\text { database (CPRD) }\end{array}$ & IPF & NA & NA & 8.65 & Crude \\
\hline NaVARATnAm [8] & 2011 & UK & $2000-2008$ & $\begin{array}{c}\text { Nationwide } \\
\text { primary care } \\
\text { database (THIN) }\end{array}$ & IPF & $\begin{array}{l}\text { ICD-9 codes for IFA } \\
\text { (515) and PF (516.3) }\end{array}$ & $\begin{array}{c}\text { Overall population of } \\
\text { the UK }\end{array}$ & 7.44 & Crude \\
\hline KoRNUM [9] & 2008 & Denmark & $1995-2000$ & $\begin{array}{c}\text { Nationwide health } \\
\text { database }\end{array}$ & $\begin{array}{c}\text { IPF } \\
\text { land ILD) }\end{array}$ & ICD-10 J84.1 & $\begin{array}{l}\text { Overall population of } \\
\text { Denmark }\end{array}$ & $\begin{array}{l}7.27 \\
4.17\end{array}$ & $\begin{array}{c}\text { Crude } \\
\text { Age-adjusted }\end{array}$ \\
\hline & & & $2001-2005$ & $\begin{array}{c}\text { Nationwide health } \\
\text { database }\end{array}$ & $\begin{array}{l}\text { IPF land } \\
\text { ILD) }\end{array}$ & ICD-10 J84.1 & & $\begin{array}{l}5.28 \\
2.91\end{array}$ & $\begin{array}{l}\text { Crude } \\
\text { Age-adjusted }\end{array}$ \\
\hline GRIBBIN [10] & 2006 & UK & $1991-2003$ & $\begin{array}{c}\text { Nationwide } \\
\text { primary care } \\
\text { database (THIN) }\end{array}$ & IPF & $\begin{array}{c}\text { Read codes for CFA, } \\
\text { IFA }\end{array}$ & Overall THIN population & 4.6 & Crude \\
\hline \multicolumn{10}{|l|}{ North America } \\
\hline Ley [11] & 2017 & NC, USA & 2000-2014 & $\begin{array}{l}\text { Health insurance } \\
\text { plan database }\end{array}$ & IPF & $\begin{array}{c}\text { ICD-9 code } 516.3 \text {, or } \\
\text { ICD-9-CM code } \\
516.31\end{array}$ & $\begin{array}{l}\text { Overall health insurance } \\
\text { plan population }\end{array}$ & $\begin{array}{c}6.8 \text { (overall) } \\
3.1 \\
\text { (per } 100000 \\
\text { person-years) }\end{array}$ & PPV-corrected \\
\hline EsPosito [12] & 2015 & USA & $2006-2012$ & $\begin{array}{c}\text { Nationwide } \\
\text { HealthCore } \\
\text { Integrated } \\
\text { Research Database }\end{array}$ & IPF & ICD-9-CM code 516.3 & $\begin{array}{l}\text { Health plan members; } \\
\text { age-adjusted value } \\
\text { applicable to overall US } \\
\text { population }\end{array}$ & $\begin{array}{c}31.9 \text { (broad } \\
\text { case } \\
\text { definition) } \\
14.6 \\
\text { (per } 100000 \\
\text { person-years) }\end{array}$ & $\begin{array}{l}\text { Age-adjusted, } \\
\text { PPV-corrected }\end{array}$ \\
\hline RAGHU [13] & 2014 & USA & $2001-2011$ & $\begin{array}{c}\text { Medicare } \\
\text { database; } 5 \% \\
\text { random sample }\end{array}$ & IPF & $\begin{array}{l}\text { ICD-9-CM } 516.3 \\
\text { and } 515 \\
\text { ICD-9-CM } 516.3\end{array}$ & $\begin{array}{l}\text { Medicare population aged } \\
\quad \geqslant 65 \text { years }\end{array}$ & $\begin{array}{l}93.7 \text { loverall) } \\
31.1-43.0 \\
\text { (broad) } \\
15.9-31.1 \\
\text { (narrow) }\end{array}$ & $\begin{array}{l}\text { Crude, patients } \\
\text { aged }>65 \text { years } \\
\text { Algorithm-defined } \\
\text { exclusions, patients } \\
\text { aged }>65 \text { years }\end{array}$ \\
\hline $\begin{array}{l}\text { FERNÁNDEZZ } \\
\text { PéREZ [14] }\end{array}$ & 2010 & $\begin{array}{l}\text { Olmsted } \\
\text { County, MN, } \\
\text { USA }\end{array}$ & $1997-2005$ & $\begin{array}{l}\text { Rochester } \\
\text { Epidemiology } \\
\text { Project (medical } \\
\text { record linkage } \\
\text { system for } \\
\text { healthcare } \\
\text { providers) }\end{array}$ & IPF & $\begin{array}{c}\text { ICD-9 code } 516.3 \\
\text { Hospital } \\
\text { International } \\
\text { Classification of } \\
\text { Diseases-Adapted } \\
\text { codes } 517 \text { and } 519\end{array}$ & $\begin{array}{l}\text { Olmsted County population } \\
\text { aged } \geqslant 50 \text { years; data } \\
\text { adjusted for applicability to } \\
\text { overall US white } \\
\text { population }\end{array}$ & $\begin{array}{l}8.8 \text { (narrow) } \\
17.4 \text { (broad) }\end{array}$ & $\begin{array}{l}\text { Age-adjusted, } \\
\text { sex-adjusted }\end{array}$ \\
\hline EHRLICH [15] & 2010 & CA, USA & $1996-2005$ & $\begin{array}{l}\text { Health insurance } \\
\text { plan database }\end{array}$ & $\begin{array}{l}\text { IPF } \\
\text { PF }\end{array}$ & ICD-9 516.3/515 & $\begin{array}{l}\text { Health plan population; } \\
\text { data adjusted for } \\
\text { applicability to overall US } \\
\text { population aged } \geqslant 18 \text { years }\end{array}$ & $\begin{array}{c}9 \\
\text { (non-diabetics) } \\
14 \text { (diabetics) }\end{array}$ & $\begin{array}{c}\text { Crude } \\
\text { Age-adjusted, by } \\
\text { diabetic status }\end{array}$ \\
\hline
\end{tabular}




\begin{tabular}{|c|c|c|c|c|c|c|c|c|c|}
\hline First author [ref.] & Year & Location & $\begin{array}{l}\text { Years } \\
\text { studied }\end{array}$ & $\begin{array}{l}\text { Data source } \\
\text { type }\end{array}$ & $\begin{array}{c}\text { Condition } \\
\text { studied }\end{array}$ & $\begin{array}{c}\text { Case } \\
\text { definition }\end{array}$ & $\begin{array}{c}\text { Population } \\
\text { demographics }\end{array}$ & $\begin{array}{c}\text { Incidence per } \\
100000 \text { per } \\
\text { year }^{\#}\end{array}$ & $\begin{array}{l}\text { Rate } \\
\text { type }\end{array}$ \\
\hline RAGHU [16] & 2006 & USA & $1996-2000$ & $\begin{array}{l}\text { Health claims } \\
\text { database }\end{array}$ & IPF & ICD-9 516.3 & $\begin{array}{l}\text { Health claims database } \\
\text { population; data adjusted } \\
\text { for applicability to overall } \\
\text { US population }\end{array}$ & $\begin{array}{l}16.3 \text { (broad) } \\
6.8 \text { (narrow) }\end{array}$ & Age-adjusted \\
\hline \multicolumn{10}{|l|}{ South America } \\
\hline Rufino [17]" & 2013 & Brazil & $1996-2010$ & $\begin{array}{c}\text { Ministry of Health } \\
\text { data }\end{array}$ & IPF & ICD-10 J84.1 & & 0.48 & Crude \\
\hline \multicolumn{10}{|c|}{ udta } \\
\hline $\mathrm{H}_{\mathrm{AN}}[18]^{\uparrow}$ & 2013 & South Korea & $1992-2010$ & $\begin{array}{l}\text { Healthcare claims } \\
\text { from insurance } \\
\text { medical cohort }\end{array}$ & IPF & NA & NA & $\begin{array}{l}4.16 \text { (broad) } \\
1.84 \text { (narrow) }\end{array}$ & $\begin{array}{c}\text { Crude, patients } \\
\quad>30 \text { years }\end{array}$ \\
\hline LAl [19] & 2012 & Taiwan & $1997-2007$ & $\begin{array}{l}\text { Health insurance } \\
\text { database/ } \\
\text { government } \\
\text { records }\end{array}$ & IPF & ICD-9 516.3 & $\begin{array}{c}\text { Population of the Taiwan } \\
\text { National Health Insurance } \\
\text { database }\end{array}$ & $\begin{array}{l}1.4 \text { (broad) } \\
1.2 \text { (narrow) }\end{array}$ & Crude \\
\hline NATSUIZAKA [20] & 2014 & $\begin{array}{l}\text { Hokkaido } \\
\text { prefecture, } \\
\text { Japan }\end{array}$ & $2003-2007$ & $\begin{array}{c}\text { Ministry of Health, } \\
\text { Labor and Welfare } \\
\text { data }\end{array}$ & IPF & $\begin{array}{l}\text { ATS/ERS consensus } \\
\text { classification }\end{array}$ & $\begin{array}{c}\text { Overall population of } \\
\text { Hokkaido }\end{array}$ & 2.23 & Crude \\
\hline
\end{tabular}

International Classification of Diseases (ICD) codes are presented as ICD-nth revision, clinical modification (CM). ICD-10 code J84.1 is currently the most specific code for IPF but may include other idiopathic interstitial pneumonia (IIP). ICD-9 code 516.3 is roughly equivalent; code 515 is "post-inflammatory fibrosis". Broad criteria were: one or more claims with a diagnostic code for IPF, but no claims for another diagnostic code for interstitial lung disease (ILD). Narrow criteria were: as for broad criteria, with a relevant diagnostic test on or before their first diagnosis date. Broad and narrow criteria were based on the 2002 American Thoracic Society (ATS)/European Respiratory Society (ERS) guidelines [21]. Probable cases were based on criteria from [22]: received a diagnosis of ILD from a rheumatologist or pulmonary physician; or ILD was the primary discharge diagnosis. Definite cases had a confirmatory diagnosis within 90 days. CPRD: Clinical Practice Research Datalink; NA: not available; THIN: The Health Improvement Network; IFA: idiopathic fibrosing alveolitis; PF: pulmonary fibrosis; CFA: cryptogenic fibrosing alveolitis; PPV: positive-predictive value; IIP: idiopathic interstitial pneumonia; IPF: idiopathic pulmonary fibrosis. \#: average incidence for the time period available; latest incidence stated where no average was given, incidence extrapolated from ILD data where percentage of IPF cases was given; ${ }^{\mathbb{1}}$ : abstract only. Reproduced and modified from [23] with permission. 
also appears to differ to that of IPF, with patients tending to be $\geqslant 50$ years old, female, nonsmokers, with no prior history of smoking $[32,35,36]$. In comparison to IPF, the prognosis for patients with iNSIP is more favourable $[32,35]$.

\section{Unclassifiable IIP}

Of all patients diagnosed with IIP, a small subgroup (15-25\%) remain unclassifiable according to current classification [21,33,37], which may be attributable to the mixed pattern of lung injury, inconclusive test results, lack of a lung biopsy due to ineligibility or lack of patient consent $[33,38]$.

\section{Incidence, prevalence and patient demographics}

In the French study performed by Duchemann et al. [24], the crude estimated prevalence of unclassifiable ILD was reported to be 0.5 per 100000 , despite surgical lung biopsies having been performed. Patients with unclassifiable ILD due to an inconclusive diagnosis were also identified from an ongoing longitudinal cohort at a specialised centre in California, USA, from 2000 to 2011. The mean age of patients with unclassifiable ILD was 68 years, similar to that observed in the IPF control group (70 years), but the proportion of male cases was lower in the unclassifiable ILD group (53\% versus $72.8 \%$; $\mathrm{p}<0.0005)$ [38]. The observed demographic profile is comparable to that reported across Europe and the USA (table 2) [39]. Among patients with unclassifiable ILD, the percentage of former smokers was lower than in the IPF control group (64\% versus $76 \%$, respectively) [38].

\section{Connective tissue disease-associated ILD}

There is a spectrum of connective tissue diseases (CTDs) characterised by an underlying mechanism of systemic autoimmunity and immune-mediated organ damage, which may develop pulmonary complications throughout the disease course [40-42]. These include rheumatoid arthritis (RA), scleroderma (systemic sclerosis (SSc)), idiopathic inflammatory myopathy (polymyositis and dermatomyositis), Sjögren's syndrome, systemic lupus erythematosus and mixed CTDs [40-43]. RA and SSc are most commonly associated with PF-ILD [43] and are discussed in further detail later.

\section{RA-associated ILD}

RA is a systemic and chronic inflammatory disease characterised by joint swelling, tenderness and destruction of synovial joints [44]. Within the RA population, clinically significant ILD occurs in 10-20\% of cases and is considered to be an important contributor to morbidity and mortality [41, 45-47]. Risk factors associated with the development of ILD in RA patients include older age, the presence of rheumatoid factor and cigarette smoking (particularly in male patients), which may promote citrullination of lung proteins leading to the development of anti-cyclic citrullinated peptide antibodies, particularly in patients who have developed the shared epitope human leukocyte antigen [48, 49].

\section{Incidence, prevalence and demographic profile}

RA is the most common autoimmune disease worldwide, with an estimated prevalence of $0.4-1 \%$ [ 40,41 , $45,50]$. Pulmonary complications are common in RA and different compartments (airway, vasculature, parenchyma and pleura) can all be involved [51]. There is considerable variation in the reported prevalence and incidence of RA-ILD, reflecting the diagnostic methods used and the populations studied [40]. However, RA-ILD is more common in men (unlike RA as a whole) and increases with older age and disease severity $[40,47]$. In a retrospective study of data recorded by centres across the UK, 230 patients

\begin{tabular}{lccccccc}
\multicolumn{7}{l}{ TABLE 2 } & Characteristics of unclassifiable interstitial lung disease patients \\
Country & Years & $\begin{array}{c}\text { Unclassifiable } \\
\text { n/total N (\%) }\end{array}$ & $\begin{array}{c}\text { With surgical } \\
\text { biopsy \% }\end{array}$ & $\begin{array}{c}\text { Male } \\
\%\end{array}$ & $\begin{array}{c}\text { Age } \\
\text { years }\end{array}$ & $\begin{array}{c}\text { FVC } \\
\%\end{array}$ & $\begin{array}{c}\text { D Lco } \\
\%\end{array}$ \\
\hline Spain & $1995-2004$ & $73 / 500(14.6)$ & 26.2 & 47 & $66.7 \pm 13.6$ & & \\
China & $1999-2009$ & $38 / 251(15.1)$ & 100 & & & & \\
Spain & $2000-2001$ & $26 / 511(5.1)$ & 22.7 & & & & \\
USA & $2000-2011$ & $132 / 1370(9.6)$ & 31 & 53 & $67.8 \pm 12.9$ & $69.0 \pm 22.1$ & $47.6 \pm 19.7$ \\
Denmark & $2003-2009$ & $62 / 431(14)$ & 34 & 45 & $59.3 \pm 14.5$ & $73.7 \pm 22.8$ & $55.8 \pm 21.4$ \\
Australia & $2011-2013$ & $23 / 232(9.9)$ & & & & &
\end{tabular}

Data are presented as mean $\pm S D$, unless otherwise stated. Blank cells represent data that were not reported. FVC: forced vital capacity; DLCO: diffusing capacity of the lung for carbon monoxide. Reproduced and modified from [39] with permission. 
were diagnosed with both RA and ILD over a 25-year period (1987-2012). The median age at diagnosis was 64 years, and the male:female ratio was 1:1.09 [48]. A review of cases treated at two centres in Korea from 1991 to 2008 indicated that 84 patients with a median age of 63 years were diagnosed with RA and usual interstitial pneumonia, with an almost equal distribution of male and female patients (52\% and $48 \%$, respectively) [52]. A retrospective analysis of mortality data from the National Center for Health Statistics in the USA from 1988 to 2004 reported 162032 mortalities associated with RA, of which 10725 (6.6\%) were attributable to RA-ILD [46]. The most common pattern on high-resolution computed tomography in patients with RA-ILD is usual interstitial pneumonia, observed in approximately two-thirds of cases [48, 53, 54].

\section{SSc-associated ILD}

SSc is a chronic autoimmune CTD of unknown aetiology, associated with considerable morbidity and increased mortality [55]. Reported percentages of patients with SSc who develop ILD range 35-90\%; SSc-ILD often manifests as NSIP and is a major cause of morbidity and mortality [56-59]. Although SSc can occur at any age, patients are usually 30-60 years of age, and women are more likely to develop SSc than men $[55,60,61]$. The cause of SSc is unknown, but its onset is associated with the interaction of environmental factors (including occupational, dietary, medical and lifestyle exposures and possibly infectious agents) in genetically predisposed individuals (e.g. African-American race) $[55,58]$.

Incidence, prevalence and demographic profile

SSc has a worldwide distribution, with a low incidence of 9-19 cases per million per year, but the reported prevalence and incidence rates vary globally, reflecting differences between the diagnostic criteria and statistical methods used when retrospectively analysing data $[55,60]$. A retrospective study published in 2008 compared epidemiological data worldwide; the prevalence of SSc was reported to range from seven cases per million in Japan (1974-1976) to 489 per million in Italy (1992) [62]. When excluding studies reporting spatiotemporal clustering or specific population surveys, the adjusted prevalence was reported to be 50-300 per million, with a higher occurrence in the USA and Australia than in Japan and Europe [62]. In Taiwan, the incidence is reported to be 10.9 cases per million, with a prevalence rate of 56 cases per million; whereas in North India, the prevalence is higher at 120 cases per million [63, 64]. In the USA, the incidence rate of SSc is reported to range 0.6-18.7 cases per million per year, with prevalence ranging 4-242 cases per million [61].

\section{Hypersensitivity pneumonitis}

Hypersensitivity pneumonitis (HP) is an immunologically initiated lung disease triggered by the repeated inhalation of a large variety of environmental organic antigens and/or chemicals, to which the genetically susceptible subject has been previously sensitised [65]. Little is known about its epidemiology worldwide, and many patients are misdiagnosed as having IPF $[66,67]$.

\section{Incidence, prevalence and demographic profile}

The epidemiology of HP is affected by geographical distribution [68-70]. Between 2011 and 2015, the incidence of occupational HP in the UK was reported to be $\sim 1.2$ cases per million workers per year, with a mean age of 52 years, and a higher rate of diagnosis in men than women ( $~ 80 \%$ of cases were male) [66]. In a cohort study of ILDs in central Denmark, $32(7 \%)$ out of 431 patients had HP at the time of inclusion; the mean age was 48.6 years and over half (63\%) were male [36]. In a retrospective, US-based database analysis of 150 million enrolees carried out from 2004 to 2013, the prevalence was observed to increase with age from 0.95 per 100000 in children aged $0-9$ years to 11.2 per 100000 in older adults aged $>65$ years, with $<50 \%$ of cases diagnosed in men [71]. Up to $25 \%$ met the criteria set for fibrotic HP (prevalence ranged $0.41-0.80$ per 100000 people), which was associated with a higher mortality rate [71]. In the epidemiological study performed by Duchemann et al. [24] in France, the prevalence of HP was 2.3 per 100000 and the incidence was 0.9 per 100000 per year.

\section{Sarcoidosis}

Sarcoidosis is a systemic disease characterised by the formation of immune granulomas in organs, especially in the lungs and lymphatic system [72]. It is estimated that up to $20 \%$ of patients diagnosed with sarcoidosis develop fibrotic lung disease, with pulmonary fibrosis presenting as dyspnoea, cough and hypoxaemia [73].

Incidence, prevalence and demographic profile

The global prevalence of sarcoidosis is estimated to be 4.7-64 in 100000 with an incidence of 1.0-35.5 in 100000 per year $[24,72,74]$. The incidence and prevalence variations correlate with age, sex, ethnic origin and geography, with the highest rates reported in northern Europe, in African-American individuals and 
predominantly in women $[72,75]$. The lowest incidence of sarcoidosis was observed in Japan, with one study of 1027 patients reporting an average incidence rate of 1.01 per 100000 population ( 0.73 for males and 1.28 for females) [72, 76].

\section{ILDs related to other occupational exposures}

A subset of patients diagnosed with ILDs related to other occupational exposures may develop a progressivefibrosing phenotype over the course of their disease, particularly those with asbestosis or silicosis [77]. Both asbestosis and silicosis are caused by the inhalation of dust, which causes lung injury and fibrosis.

\section{Asbestosis}

The prevalence of asbestosis is decreasing worldwide as occupational exposure is decreasing; however, the use of asbestos in commerce and industry remains high in Africa, Asia and South America [77]. In Australia, there were 2041 hospitalisations for asbestosis between 1998 and 2015 [78]. In the UK, the majority of cases of asbestosis are the result of historical exposure [79]. In a retrospective analysis of long-latency respiratory disease (LLRD) between 1996 and 2014, the average annual incidence rate of pneumoconiosis associated with asbestos was 1.9 per 100000 males (95\% CI 1.7-2.2) [79]. The incidence of LLRD including pneumoconiosis, the vast majority of which were attributable to occupational asbestosis exposure, peaked in men and women aged 75-79 years [79].

\section{Silicosis}

The prevalence of silicosis is also linked with occupational exposure to free crystalline silicon dioxide or silica, and generally occurs in patients after the exposure has ended [80,81]. Establishing the prevalence of silicosis is difficult due to the number of industries at risk, the nature of industrial employment, which is often transient, the delayed onset of symptoms post-exposure and the nature of data sources available [77, 82, 83].

The prevalence of silicosis is reported to be higher in low- and middle-income countries (e.g. China, Brazil, South Africa) but is also an important health concern in Europe and the USA [81]. Manual workers in low- or middle-income countries often forego the use of control measures such as personal protective equipment, and this could be a contributor to the differences observed between countries [84-86]. Silicosis was first reported in South African gold miners in the early 1900s, and South Africa now has one of the highest rates of silicosis worldwide [87]. There are an estimated 500000 mineworkers across Southern Africa (Lesotho, Mozambique and Swaziland) and 1.5-2 million ex-mineworkers [88]. In South Africa alone, the proportion of miners diagnosed with silicosis increased from 3\% to $33 \%$ in black miners and $18 \%$ to $22 \%$ in white miners between 1975 and 2007 [87]. In 2013, 8095 cases of silicosis were reported in China, with its prevalence continuing to increase over the past decade [89]. In comparison, in the USA, silicosis was the underlying or contributing cause of 1437 mortalities between 2001 and 2010, with a decline in mortality rate from 0.74 per 1 -million population in 2001 to 0.39 per million in 2010 [83]. The majority of patients diagnosed with silicosis were male (95.3\%), white (86\%) and over 45 years of age (98.1\%) [83]. In the UK, there are an estimated 20-50 cases of silicosis diagnosed per year, with 10-20 mortalities annually [82]. The majority of cases are reported in men (based on data between 2005 and 2016) [82].

\section{Conclusion}

Despite the global distribution of ILDs with a progressive-fibrosing phenotype, their incidence and prevalence are not well defined. This may be related to a number of reasons, potentially to the heterogeneous nature of the aetiology, the complexity of diagnosis (and subsequent recording of cases), the low numbers of patients diagnosed and the methods employed to retrospectively analyse patient databases. ILDs that may present a progressive-fibrosing phenotype appear to be more common in older adults and are associated with a complex network of environmental and genetic factors. Few of the available epidemiological data are from low- or middle-income countries; this may be attributable to factors such as the availability of high-resolution computed tomography and access to healthcare professionals with the expertise needed to differentiate between ILDs. Given the negative associated prognosis, further epidemiological studies are warranted to help identify ILD patients who may develop a progressive-fibrosing phenotype and enable effective clinical management.

Acknowledgements: The authors meet criteria for authorship as recommended by the International Committee of Medical Journal Editors (ICMJE). Writing assistance was provided by Bethany Degg of GeoMed, an Ashfield company, part of UDG Healthcare plc, which was contracted and funded by Boehringer Ingelheim Pharmaceuticals, Inc. (BIPI). BIPI was given the opportunity to review the manuscript for medical and scientific accuracy as well as intellectual property considerations.

Conflict of interest: A.L. Olson reports receiving the following, outside the submitted work: support from United Therapeutics for study enrolment IPF; support from Boehringer Ingelheim for unbranded IPF talks; support from France Foundation and the PILOT Program for project development for IPF/speaker/content development on talks for 
IPF; a grant from Bellerophon Pulse Technologies; and support from Boehringer Ingelheim Speaker's Bureau, Boehringer Ingelheim Consultancy, Genentech Advisory Board, Genentech Consultancy Services and Vindico CME Educational Development. A.H. Gifford reports receiving nonfinancial support from Ashfield Healthcare Communications (part of UDG Healthcare pc) for assistance with preparation of the current work. A.H. Gifford also received personal fees from Grifols, outside the submitted work. N. Inase has nothing to disclose. E.R. Fernández Pérez reports receiving personal fees from BI, outside the submitted work. T. Suda has nothing to disclose.

Support statement: The authors received no direct compensation related to the development of the manuscript. Writing assistance was contracted and funded by Boehringer Ingelheim Pharmaceuticals Inc. (BIPI).

\section{References}

1 Raghu G. Interstitial lung disease. In: Goldman L, Schafer A. Goldman's Cecil Medicine. 25th Edn. Philadelphia, Saunders, 2016; pp. 575-588.

2 Flaherty KR, Brown KK, Wells AU, et al. Design of the PF-ILD trial: a double-blind, randomised, placebo-controlled phase III trial of nintedanib in patients with progressive fibrosing interstitial lung disease. $B M$ J Open Respir Res 2017; 4: e000212.

3 Wells AU, Brown KK, Flaherty KR, et al. What's in a name? That which we call IPF, by any other name would act the same. Eur Respir J 2018; 51: 1800692.

4 Raghu G, Collard HR, Egan JJ, et al. An official ATS/ERS/JRS/ALAT statement: idiopathic pulmonary fibrosis: evidence-based guidelines for diagnosis and management. Am J Respir Crit Care Med 2011; 183: 788-824.

5 Cottin V, Hirani NA, Hotchkin DL, et al. Presentation, diagnosis and clinical course of the spectrum of progressive-fibrosing interstitial lung diseases. Eur Respir Rev 2018; 27: 180076.

6 British Lung Foundation. Idiopathic pulmonary fibrosis. 2016. https://www.blf.org.uk/sites/default/files/4.\% 20IPFpdf Date last updated: September 2016. Date last accessed: January 2018.

7 Maher T, Strongman H, Boggon R, et al. Idiopathic pulmonary fibrosis survival has not improved in the 21st century; analysis of CPRD gold primary care data. Thorax 2013; 68: A82-AA3.

8 Navaratnam V, Fleming KM, West J, et al. The rising incidence of idiopathic pulmonary fibrosis in the UK. Thorax 2011; 66: 462-467.

9 Kornum JB, Christensen S, Grijota M, et al. The incidence of interstitial lung disease 1995-2005: a Danish nationwide population-based study. BMC Pulm Med 2008; 8: 24

10 Gribbin J, Hubbard RB, Le Jeune I, et al. Incidence and mortality of idiopathic pulmonary fibrosis and sarcoidosis in the UK. Thorax 2006; 61: 980-985.

11 Ley B, Urbania T, Husson G, et al. Code-based diagnostic algorithms for idiopathic pulmonary fibrosis. Case validation and improvement. Ann Am Thorac Soc 2017; 14: 880-887.

12 Esposito DB, Lanes S, Donneyong M, et al. Idiopathic pulmonary fibrosis in United States automated claims. Incidence, prevalence, and algorithm validation. Am J Respir Crit Care Med 2015; 192: 1200-1207.

13 Raghu G, Chen SY, Yeh WS, et al. Idiopathic pulmonary fibrosis in US Medicare beneficiaries aged 65 years and older: incidence, prevalence, and survival, 2001-11. Lancet Respir Med 2014; 2: 566-572.

14 Fernández Pérez ER, Daniels CE, Schroeder DR, et al. Incidence, prevalence, and clinical course of idiopathic pulmonary fibrosis: a population-based study. Chest 2010; 137: 129-137.

15 Ehrlich SF, Quesenberry CP Jr, Van Den Eeden SK, et al. Patients diagnosed with diabetes are at increased risk for asthma, chronic obstructive pulmonary disease, pulmonary fibrosis, and pneumonia but not lung cancer. Diabetes Care 2010; 33: 55-60.

16 Raghu G, Weycker D, Edelsberg J, et al. Incidence and prevalence of idiopathic pulmonary fibrosis. Am J Respir Crit Care Med 2006; 174: 810-816.

17 Rufino RL, Costa CHD, Accar J, et al. Incidence and mortality of interstitial pulmonary fibrosis in Brazil. Am J Respir Crit Care Med 2013: A1458.

18 Han S, Mok Y, Jee SH, et al. Incidence and mortality of idiopathic pulmonary fibrosis In South Korea. Am J Respir Crit Care Med 2013; 187: A1460.

19 Lai CC, Wang CY, Lu HM, et al. Idiopathic pulmonary fibrosis in Taiwan - a population-based study. Respir Med 2012; 106: 1566-1574

20 Natsuizaka M, Chiba H, Kuronuma K, et al. Epidemiologic survey of Japanese patients with idiopathic pulmonary fibrosis and investigation of ethnic differences. Am J Respir Crit Care Med 2014; 190: 773-779.

21 American Thoracic Society/European Respiratory Society international multidisciplinary consensus classification of the idiopathic interstitial pneumonias. Am J Respir Crit Care Med 2002; 165: 277-304.

22 Saad N, Camus P, Suissa S, et al. Statins and the risk of interstitial lung disease: a cohort study. Thorax 2013; 68: 361-364.

23 Hutchinson J, Fogarty A, Hubbard R, et al. Global incidence and mortality of idiopathic pulmonary fibrosis: a systematic review. Eur Respir J 2015; 46: 795-806.

24 Duchemann B, Annesi-Maesano I, Jacobe de Naurois C, et al. Prevalence and incidence of interstitial lung diseases in a multi-ethnic county of Greater Paris. Eur Respir J 2017; 50: 1602419.

25 Richeldi L, Rubin AS, Avdeev S, et al. Idiopathic pulmonary fibrosis in BRIC countries: the cases of Brazil, Russia, India, and China. BMC Med 2015; 13: 237.

26 Hopkins RB, Burke N, Fell C, et al. Epidemiology and survival of idiopathic pulmonary fibrosis from national data in Canada. Eur Respir J 2016; 48: 187-195.

27 Richeldi L, Collard HR, Jones MG. Idiopathic pulmonary fibrosis. Lancet 2017; 389: 1941-1952.

28 Tsakiri KD, Cronkhite JT, Kuan PJ, et al. Adult-onset pulmonary fibrosis caused by mutations in telomerase. Proc Natl Acad Sci USA 2007; 104: 7552-7557.

29 Harari S, Madotto F, Caminati A, et al. Epidemiology of idiopathic pulmonary fibrosis in Northern Italy. PLOS ONE 2016; 11: e0147072.

30 Talbert J, Scwartz D. Pulmonary Fibrosis, Familial. Seattle, University of Washington, 2005.

31 Lee HL, Ryu JH, Wittmer MH, et al. Familial idiopathic pulmonary fibrosis: clinical features and outcome. Chest 2005; 127: 2034-2041. 
32 Travis WD, Hunninghake G, King TE Jr, et al. Idiopathic nonspecific interstitial pneumonia: report of an American Thoracic Society project. Am J Respir Crit Care Med 2008; 177: 1338-1347.

33 Travis WD, Costabel U, Hansell DM, et al. An official American Thoracic Society/European Respiratory Society statement: update of the international multidisciplinary classification of the idiopathic interstitial pneumonias. $A m$ J Respir Crit Care Med 2013; 188: 733-748.

34 Bagnato G, Harari S. Cellular interactions in the pathogenesis of interstitial lung diseases. Eur Respir Rev 2015; 24: 102-114.

35 Belloli EA, Beckford R, Hadley R, et al. Idiopathic non-specific interstitial pneumonia. Respirology 2016; 21: 259-268.

36 Hyldgaard C, Hilberg O, Muller A, et al. A cohort study of interstitial lung diseases in central Denmark. Respir Med 2014; 108: 793-799.

37 Bendstrup E, Maher TM, Manali ED, et al. Challenges in the classification of fibrotic ILD. Sarcoidosis Vasc Diffuse Lung Dis 2015; 32: Suppl. 1, 4-9.

38 Ryerson CJ, Urbania TH, Richeldi L, et al. Prevalence and prognosis of unclassifiable interstitial lung disease. Eur Respir J 2013; 42: 750-757.

39 Skolnik K, Ryerson CJ. Unclassifiable interstitial lung disease: a review. Respirology 2016; 21: 51-56.

40 Olson AL, Brown KK, Fischer A. Connective tissue disease-associated lung disease. Immunol Allergy Clin North Am 2012; 32: 513-536.

41 Mathai SC, Danoff SK. Management of interstitial lung disease associated with connective tissue disease. BMJ 2016; 352: h6819.

42 Fischer A, Antoniou KM, Brown KK, et al. An official European Respiratory Society/American Thoracic Society research statement: interstitial pneumonia with autoimmune features. Eur Respir J 2015; 46: 976-987.

43 Cottin V. Idiopathic interstitial pneumonias with connective tissue diseases features: a review. Respirology 2016; 21 245-258.

44 Aletaha D, Neogi T, Silman AJ, et al. 2010 Rheumatoid arthritis classification criteria: an American College of Rheumatology/European League Against Rheumatism collaborative initiative. Arthritis Rheum 2010; 62: 2569-2581.

45 Iqbal K, Kelly C. Treatment of rheumatoid arthritis-associated interstitial lung disease: a perspective review. Ther Adv Musculoskelet Dis 2015; 7: 247-267.

46 Olson AL, Swigris JJ, Sprunger DB, et al. Rheumatoid arthritis-interstitial lung disease-associated mortality. Am J Respir Crit Care Med 2011; 183: 372-378.

47 Bongartz T, Nannini C, Medina-Velasquez YF, et al. Incidence and mortality of interstitial lung disease in rheumatoid arthritis: a population-based study. Arthritis Rheum 2010; 62: 1583-1591.

48 Kelly CA, Saravanan V, Nisar M, et al. Rheumatoid arthritis-related interstitial lung disease: associations, prognostic factors and physiological and radiological characteristics - a large multicentre UK study. Rheumatology (Oxford) 2014; 53: 1676-1682.

49 Shaw M, Collins BF, Ho LA, et al. Rheumatoid arthritis-associated lung disease. Eur Respir Rev 2015; 24 : 1-16.

50 Zeng X-F, Zhu S-I, Tan A-C, et al. Disease burden and quality of life of rheumatoid arthritis in China: a systematic review. Chin J Evid Based Med 2013; 13: 300-307.

51 Brown KK. Rheumatoid lung disease. Proc Am Thorac Soc 2007; 4: 443-448.

52 Song JW, Lee HK, Lee CK, et al. Clinical course and outcome of rheumatoid arthritis-related usual interstitia pneumonia. Sarcoidosis Vasc Diffuse Lung Dis 2013; 30: 103-112.

53 Assayag D, Lee JS, King TE Jr. Rheumatoid arthritis associated interstitial lung disease: a review. Medicina (B Aires) 2014; 74: 158-165.

54 Lee HK, Kim DS, Yoo B, et al. Histopathologic pattern and clinical features of rheumatoid arthritis-associated interstitial lung disease. Chest 2005; 127: 2019-2027.

55 Varga J. Systemic sclerosis (scleroderma). In: Goldman L, Schafer AL, eds. Goldman-Cecil Medicine. 25th Edn. Philadelphia, Saunders, 2016; pp. 1777-1784.

56 Cappelli S, Bellando Randone S, Camiciottoli G, et al. Interstitial lung disease in systemic sclerosis: where do we stand? Eur Respir Rev 2015; 24: 411-419.

57 Goh NS, Desai SR, Veeraraghavan S, et al. Interstitial lung disease in systemic sclerosis: a simple staging system. Am J Respir Crit Care Med 2008; 177: 1248-1254.

58 Volkmann ER, Tashkin DP. Treatment of systemic sclerosis-related interstitial lung disease: a review of existing and emerging therapies. Ann Am Thorac Soc 2016; 13: 2045-2056.

59 Schoenfeld SR, Castelino FV. Interstitial lung disease in scleroderma. Rheum Dis Clin North Am 2015; 41: 237-248.

60 Walker UA, Tyndall A, Czirjak L, et al. Clinical risk assessment of organ manifestations in systemic sclerosis: a report from the EULAR Scleroderma Trials and Research group database. Ann Rheum Dis 2007; 66: 754-763.

61 Mayes MD. Scleroderma epidemiology. Rheum Dis Clin North Am 2003; 29: 239-254.

62 Chifflot H, Fautrel B, Sordet C, et al. Incidence and prevalence of systemic sclerosis: a systematic literature review. Semin Arthritis Rheum 2008; 37: 223-235.

63 Barnes J, Mayes MD. Epidemiology of systemic sclerosis: incidence, prevalence, survival, risk factors, malignancy, and environmental triggers. Curr Opin Rheumatol 2012; 24: 165-170.

64 Kuo CF, See LC, Yu KH, et al. Epidemiology and mortality of systemic sclerosis: a nationwide population study in Taiwan. Scand J Rheumatol 2011; 40: 373-378.

65 Fernandez Perez ER, Swigris JJ, Forssen AV, et al. Identifying an inciting antigen is associated with improved survival in patients with chronic hypersensitivity pneumonitis. Chest 2013; 144: 1644-1651.

66 Barber C, Wiggans R, Carder M, et al. Epidemiology of occupational hypersensitivity pneumonitis; reports from the SWORD scheme in the UK from 1996 to 2015. Occup Environ Med 2017; 74: 528-530.

67 Morell F, Villar A, Montero MA, et al. Chronic hypersensitivity pneumonitis in patients diagnosed with idiopathic pulmonary fibrosis: a prospective case-cohort study. Lancet Respir Med 2013; 1: 685-694.

68 Thomeer MJ, Costabe U, Rizzato G, et al. Comparison of registries of interstitial lung diseases in three European countries. Eur Respir J 2001; 18: Suppl. 32, 114s-118s.

69 Bang KM, Weissman DN, Pinheiro GA, et al. Twenty-three years of hypersensitivity pneumonitis mortality surveillance in the United States. Am J Ind Med 2006; 49: 997-1004. 
70 Okamoto T, Miyazaki Y, Ogura T, et al. Nationwide epidemiological survey of chronic hypersensitivity pneumonitis in Japan. Respir Investig 2013; 51: 191-199.

71 Fernandez Perez ER, Kong AM, Raimundo K, et al. Epidemiology of hypersensitivity pneumonitis among an insured population in the United States: a claims-based cohort analysis. Ann Am Thorac Soc 2018; 15: 460-469.

72 Valeyre D, Prasse A, Nunes H, et al. Sarcoidosis. Lancet 2014; 383: 1155-1167.

73 Patterson KC, Strek ME. Pulmonary fibrosis in sarcoidosis. Clinical features and outcomes. Ann Am Thorac Soc 2013; 10: 362-370.

74 Arkema EV, Grunewald J, Kullberg S, et al. Sarcoidosis incidence and prevalence: a nationwide register-based assessment in Sweden. Eur Respir J 2016; 48: 1690-1699.

75 Baughman RP, Field S, Costabel U, et al. Sarcoidosis in America. Analysis based on health care use. Ann Am Thorac Soc 2016; 13: 1244-1252.

76 Morimoto T, Azuma A, Abe S, et al. Epidemiology of sarcoidosis in Japan. Eur Respir J 2008; 31: 372-379.

77 Cowie R, Becklake M. Pneumoconioses. In: Murray \& Nadel's Textbook of Respiratory Medicine. 6th Edn. Philadelphia, Elsevier, 2016; pp. 1307-1330.

78 Soeberg M, Vallance DA, Keena V, et al. Australia's ongoing legacy of asbestos: Significant challenges remain even after the complete banning of asbestos almost fifteen years ago. Int J Environ Res Public Health 2018; 15 : 384.

79 Carder M, Darnton A, Gittins M, et al. Chest physician-reported, work-related, long-latency respiratory disease in Great Britain. Eur Respir J 2017; 50: 1700961.

80 Beckett W. Adverse effects of crystalline silica exposure. American Thoracic Society Committee of the Scientific Assembly on Environmental and Occupational Health. Am J Respir Crit Care Med 1997; 155: 761-768.

81 Leung CC, Yu IT, Chen W. Silicosis. Lancet 2012; 379: 2008-2018.

82 Health and Safety Executive (HSE) UK. Silicosis and coal workers' pneumoconiosis. 2018. www.hse.gov.uk/ statistics/causdis/pneumoconiosis-and-silicosis.pdf. Date last updated: October 2018. Date last accessed: December 2018.

83 Bang KM, Mazurek JM, Wood JM, et al. Silicosis mortality trends and new exposures to respirable crystalline silica - United States, 2001-2010. MMWR Morb Mortal Wkly Rep 2015; 64: 117-120.

84 Bakhsh K, Ahmad N, Tabasum S, et al. Health hazards and adoption of personal protective equipment during cotton harvesting in Pakistan. Sci Total Environ 2017; 598: 1058-1064.

85 Blanco-Munoz J, Lacasana M. Practices in pesticide handling and the use of personal protective equipment in Mexican agricultural workers. J Agromedicine 2011; 16: 117-126.

86 Izudi J, Ninsiima V, Alege JB. Use of personal protective equipment among building construction workers in Kampala, Uganda. J Environ Public Health 2017; 2017: 7930589.

87 Nelson G. Occupational respiratory diseases in the South African mining industry. Glob Health Action 2013; 6: 19520.

88 The World Bank. Benefits and costs of reducing tuberculosis among Southern Africa's mineworkers - overview. 2014. Washington, DC, World Bank Group, 2014. http://pubdocs.worldbank.org/en/770861483124917730/WorldBank-economic-analysis-on-addressing-TB-in-the-mines-brief.pdf. Date last updated: March 2014. Date last accessed: December 2018

89 Tse LA, Dai J, Chen M, et al. Prediction models and risk assessment for silicosis using a retrospective cohort study among workers exposed to silica in China. Sci Rep 2015; 5: 11059. 